\title{
Response of Pear (Le Conte cv.) Trees Grown in Calcareous Soil to Trunk Injection and Foliar Application of some Micronutrients
}

\author{
Zaen El-Deen, E. M. A. ${ }^{1}$ M. F. Attia ${ }^{2}$ and Sheren, A. Abd EL-Hamied ${ }^{1}$

\section{ABSTRACT} \\ reaction, nucleic acid metabolism and protein \\ biosynthesis.
}

This study was conducted during the two successive seasons 2016 and 2017 on eleven years old Le Conte pear trees budded on (Pyrus betulaefolia) rootstock grown in a private orchard located at El-Hamam, Matrouh Governorate, Egypt to overcome micronutrients deficiency problems in calcareous soils . A commercial mixture of $5 \%$ w/w Fe, $2.48 \%$ w/w $\mathrm{Zn}$ and $3.5 \%$ w/w Mn nutrients dissolved in water and chelated with EDTA were used in three application methods( i.e. control, (SA)soil application $50 \mathrm{~g} /$ tree, (FA) foliar application at $0.5,0.75 \& 1 \mathrm{~g} / \mathrm{L}$ and (TI) trunk injection at $0.5,0.75 \& 1 \mathrm{~g} / \mathrm{L}$. The application repeated three times a year (at beginning of growth season in "March", at fruit maturity in "June" and after harvesting in "August"). The obtained results revealed that all trunk injection and foliar application treatments were very effective in solving micronutrients deficiency problems than soil application thus stimulate growth parameters (leaf width, leaf length, leaf area and total chlorophyll) and leaf mineral contents. The increase in the growth parameters and leaf mineral contents led to improve yield/ tree and fruit quality. Generally, trunk injection $(1 \mathrm{~g} / \mathrm{L})$ was the best treatments which gave the highest growth parameters, leaf mineral contents, yield/ tree, fruit length, diameter, weight, volume, total sugar, TSS, and decreased total acidity in both studied seasons.

Key words: Pear, Calcareous soil, Trunk injection, foliar application, Micronutrients.

\section{INTRODUCTION}

Pear (Pyrus communis, L.) is one of the important deciduous fruits trees grown in Egypt. It can be grown in a wide range of climatic conditions as it can tolerate as low as $-26^{\circ} \mathrm{C}$ temperature when dormant and as high as $45^{\circ} \mathrm{C}$ during growing period. A large number of pear cultivars require about 1200 hours below $7^{\circ} \mathrm{C}$ during winter to meet their chilling requirements to flower and fruit satisfactorily.

Microelements deficiency is rarely caused through insufficient in the soil but usually because it is rendered unavailable for the uptake by alkaline soil conditions. Fruit trees grown in calcareous soils suffer from microelements deficiency mainly because the reduction of their availability as they form insoluble complex with the calcium carbonate (Swietlik, 2002). This problem of high $\mathrm{pH}$ of calcareous soils is often described as lime induced chlorosis. This problem affects photosynthesis
Fertilizers can be applied directly on the soil and by foliar application via fertigation. However, methods of supplying nutrients by injections to tree trunks directly are approved in recent years. This system applies the nutrients directly to the current xylem by moving to the needed areas, allows easy and economical application of aqueous solutions to woody species Navarro et al., (1992).

Trunk injection is one of the efficient methods of fertilizers application compared with conventional methods of plant nutrition which depend on fertilization through soil specially in particular cases (high $\mathrm{pH}$ values of the soil solution, high $\mathrm{CaCO}_{3}$ content, high salinity, etc.). Using this method could help to solve absorption problem Abdi and Hedayat (2010). When using this method, there is no weed control because they never competed with tree roots for nutrients absorption. There is no use of any herbicides or soil fertilization, subsequently no leaching of these components in the underground water and no pollution, which led to conservation Mahmoud (2009).

Foliar micronutrient is one method which enhances plant nutritional status during the growing season especially when the soil conditions are not suitable for the absorption of elements such as, high soil $\mathrm{pH}$, presence of calcium carbonate and loss by washing Mohamad et al., (2017).

Microelements are essential for fruit trees growth, yield and fruit quality Shoeib and El- Sayyed (2003), Asaad, (2014), Başar (2003) and Álvarez-Fernández et al., (2004)and Atallah et al. (2010) stated that Fe, Zn and $\mathrm{Mn}$ are of the most important micronutrients for pears grown in calcareous or alkaline soils, in the Mediterranean zone climate.

Many researches indicated that micronutrients are very useful for all fruit trees. Mohamad et al., (2017) Mentioned that iron is very important for Le Conte pear trees. They reminded that a foliar application of $\mathrm{Fe}$ nutrient has an important positive effect on the yield and quality. Iron increases photosynthesis and carbohydrate synthesis and in reproductive growth of fruit Sohrab et al., (2013). So increasing the photosynthesis, lead to

${ }^{1}$ Plant production Dept.,

${ }^{2}$ Soil Fertility and Microbiology Dept., Desert research center, (Egypt) Received December 01, 2018, Accepted December 26, 2018 
increase the sugar compounds and cause more soluble solids in fruit juice Ram and Bose (2000).

Alloway, B.J. (2008) and El-Khawga (2007) stated that foliar application of $4000(\mathrm{ppm})$ zinc sulphate on pomegranate trees resulted in the highest TSS, minimum acidity and maximum total sugar. Bakshi et al., (2013) Reported that the plants treated with 0.6 per cent $\mathrm{ZnSO}_{4}$ showed highest TSS, ascorbic acid, TSS/acid ratio and lowest acidity of strawberry. Waskela et al., (2013) Reported that, the maximum weight, length and width of fruit were obtained with the foliar application of $0.75 \%$ zinc sulphate in guava.

Manganese is necessary of chlorophyll formation that enhances photosynthesis. It is only moderately mobile in plant tissues so symptoms appear on younger leaves first, most often in those leaves just reaching their full size. Soil application of manganese can be ineffective due to immobilization especially in heavier soils or soils which have been over limed. Moazzam et al., (2011) observed that the foliar application of $0.4 \%$ $\mathrm{FeSO}_{4}+0.8 \% \mathrm{H}_{3} \mathrm{BO}_{3}+0.8 \% \mathrm{ZnSO}_{4}$ gave maximum pulp weight, minimum stone weight, minimum peel weight, highest TSS, total sugar and minimum acidity as compared to control in mango fruit. Yadav et al., (2013) reported that the highest fruit weight, length, diameter, and fruit volume obtained with foliar application of $0.1 \% \mathrm{H}_{3} \mathrm{BO}_{3}+0.5 \% \mathrm{ZnSO}_{4}, 7 \mathrm{H}_{2} \mathrm{O}+0.5$ $\% \mathrm{FeSO}_{4}, 7 \mathrm{H}_{2} \mathrm{O}$ on low-chill peach.

The mentioned results above indicated that fruit trees, particularly pears which are grown in calcareous soils, suffer from nutrients deficiency, especially micronutrients (i.e. Fe, $\mathrm{Mn}$ and $\mathrm{Zn}$ ). This is due to the high $\mathrm{pH}$ of the soil, which leads to the precipitation of micronutrients as insoluble or low soluble forms as hydroxides or complexes, as well as the presence of calcium carbonate, especially active carbonate which has large specific area that increases the adsorption of micronutrients on their active surface significantly higher than the ability of plant roots to absorb these nutrients.

Therefore, this research aims to use different fertilization methods, especially fertilization by trunk injection in comparison with fertigation and foliar application 'to increase the efficiency of the utilization of micronutrients fertilizers added to pear trees grown in calcareous soils to overcome micronutrients deficiency problems.

\section{MATERIALS AND METHODS}

This study were conducted through the two successive seasons of 2016 and 2017 on eleven years old Le Conte pear trees budded on (Pyrus betulaefolia) rootstock grown in calcareous soil in an orchard located at El-Hamam, Matrouh Governorate, Egypt to overcome micronutrients deficiency problems. Fifty four trees are similar in vigor spaced $5 \times 5 \mathrm{~m}$ under drip irrigation system. All trees received the same agricultural and horticultural practices that are recommended by The Egyptian Ministry of Agriculture and Land Reclamation. The soil and irrigation water analysis of the experimental orchard characteristics are shown in table (1) and (2). A commercial mixture of $5 \% \mathrm{w} / \mathrm{w} \mathrm{Fe}$, $2.48 \% \mathrm{w} / \mathrm{w} \mathrm{Zn}$ and $3.5 \% \mathrm{w} / \mathrm{w}$ Mn nutrients dissolved in water and chelated with EDTA were used in three applications methods ( i.e. control, (SA) soil application $50 \mathrm{~g} /$ tree, (FA) foliar application at $0.5,0.75 \& 1 \mathrm{~g} / \mathrm{L}$ and (TI) trunk injection at $0.5,0.75 \& 1 \mathrm{~g} / \mathrm{L}$. The application repeated three times a year (at beginning of growth season in "March", at fruit maturity in "June" and after harvesting in "August"). The study had seven treatments in a simple experiment which arranged in a complete randomized block design in three replicates and two trees for each.

\section{Trunk injection method:}

During the rest period "on January" the preparation for trunk injection was conducted as follows: (a) Measuring the tree trunk diameter; (b) performing a hole (6 mm-diameter) drilled to radius of the trunk where xylem was found, (c) The injector hammered into the hole, (d) The hole around the injector was filled with silicon, (e) The opened end of the tube joined to the bottles of the nutrient solutions by suitable tubes each has a valve to control the flow of each one. All bottles were hang above the injection hole.

Table 1. Experimental soil physical and chemical properties

\begin{tabular}{|c|c|c|c|c|c|c|c|}
\hline \multirow{2}{*}{\multicolumn{2}{|c|}{ Particle size distribution }} & $\begin{array}{c}\text { Coarse } \\
\text { Sand }\end{array}$ & Fine sand & Silt & Clay & \multicolumn{2}{|c|}{ Soil texture } \\
\hline & & 12.06 & 50.8 & 22.71 & 14.43 & Sandy 1 & \\
\hline \multirow{5}{*}{ Chemical analysis } & pH & $\begin{array}{c}E C \\
\mathbf{d S m}^{-1}\end{array}$ & $\begin{array}{c}\text { CEC } \\
\text { mmlckg }^{-1}\end{array}$ & $\begin{array}{l}\text { O.M. } \\
\text { gkg-1 }^{-1}\end{array}$ & $\begin{array}{c}\text { Total } \\
\mathrm{CaCO}_{3} \%\end{array}$ & $\begin{array}{c}\text { Active } \\
\mathrm{CaCO}_{3} \%\end{array}$ & $\begin{array}{l}\text { OC } \\
(\%)\end{array}$ \\
\hline & 8.33 & 2.2 & 70.8 & 11 & 45.91 & 10.64 & 0.83 \\
\hline & \multicolumn{7}{|c|}{ Available nutrients $\left(\mathrm{mgkg}^{-1}\right)$} \\
\hline & $\mathbf{N}$ & $\mathbf{P}$ & $\mathbf{K}$ & $\mathbf{F e}$ & $\mathrm{Zn}$ & Mn & $\mathbf{C u}$ \\
\hline & 395 & 2.2 & 205 & 4.8 & 0.2 & 3.5 & 1.5 \\
\hline
\end{tabular}


Table 2. Chemical analysis of experimental irrigation water

\begin{tabular}{cccccccccc}
\hline \multirow{2}{*}{$\mathbf{p H}$} & $\mathbf{E C}$ & \multicolumn{4}{c}{ Soluble cations $\left(\mathbf{m e q L}^{-\mathbf{1}}\right)$} & \multicolumn{3}{c}{ Soluble anions $\left(\mathbf{m e q L}^{-\mathbf{1}}\right)$} & \multirow{2}{*}{ SAR } \\
\cline { 3 - 11 } & $\left(\mathbf{d S m}^{-1}\right)$ & $\mathbf{N a}$ & $\mathbf{K}$ & $\mathbf{C a}$ & $\mathbf{M g}$ & $\mathbf{H}_{2} \mathbf{C O}_{3}$ & $\mathbf{C l}$ & $\mathbf{S O}_{\mathbf{4}}$ & \\
\hline 7.50 & 0.75 & 2.38 & 1.77 & 2.00 & 1.35 & 4.80 & 1.70 & 1.00 & 1.84 \\
\hline
\end{tabular}

Leaf width and length At the end of August vegetative samples from mature leaves were collected then leaf width and length were measured.

Leaf area $\left(\mathbf{c m}^{2}\right)$ was determined by leaf area meter Model Ci 2003 apparatus (USA made).

Average total chlorophyll content was measured using a chlorophyll meter SPAD 502.

Leaf nutrient contents for determining leaf nutrient contents samples were collected at the second half of August. Thirty leaves /tree were collected representing the four main directions. Collected samples prepared and analyzed for macro and micronutrients by wet digestion of plant material which carried out using hydrogen peroxide and sulfuric acid as recommended by Parkinson and Allen (1975). Total nitrogen was determined in digested samples by semi-micro Kjeldahl methods as recommended by Bremner (1965). Phosphorus was calorimetrically determined using the molybdenum method according to Chapman and Pratt (1961). Potassium was determined by the flame photometer as outlined by Jackson (1958). Fe, Mn and Zn were determined using the Elmer atomic absorption spectrophotometer. .

Yield: The yield of the experimental trees was harvested through the second half of July in each season. The following parameters were determined:

\section{Fruit physical properties:}

Samples consist of 10 full mature fruits were randomly selected from each tree and the fruit weight, volume, length and diameter were determined and recorded.

\section{Fruit chemical properties:}

50 gram from ripe fruits were blended in $100 \mathrm{ml}$ distilled water using special electric mixer, then filtered for analysis as outlined by A.O.A.C (2000). Total soluble solids (T.S.S.) in fruit juice were determined using Carl Zeiss hand refractometer. Total sugars percentage was determined according to Smith, et al., (1956). Total acidity percentage in fruit juice was determined according to A.O.A.C (2000).

\section{Evaluation of the treatment efficiency:}

To evaluate the efficiency of the three application methods (for each experimental season), the traditional method of nutrient application (soil application) (SA) was the base that the percentage rationing accounted against. The same calculation applied between (TI) and (FA). The percentage of superiority calculated as follows:

The difference between the highest value of such variable (v) due to FA or TI treatments and the value of SA were:

FA compared to $\mathrm{SA}=((\mathrm{FA}) \mathrm{v}-(\mathrm{SA})) /(\mathrm{SA}) * 100$

TI compared to $\mathrm{SA}=((\mathrm{TI}) \mathrm{v}-(\mathrm{SA})) /(\mathrm{SA}) * 100$

Also the different between (TI) and (FA) calculated as the same

TI compared to FA $=((\mathrm{TI}) \mathrm{v}-(\mathrm{FA}) \mathrm{v}) /(\mathrm{FA}) \mathrm{v} * 100$

The average of the superiority percentage for the two seasons calculated

\section{Statistical and Economic analysis:}

All data were statistically analyzed according to the technique of analysis of variance (ANOVA) as published by Gomez and Gomez (1984), using "SAS 9.1.3" Computer software package. Least Significant Differences (LSD) at 5\% was used to test the differences between treatment means. For economic analysis, benefit to cost was calculated for all the treatments using prevailing prices of inputs and pear yield/fed, treatment net return $=$ treatment benefit - treatment cost where, treatment benefit $=$ average increase in yield due to treatments $\mathrm{x}$ average price where, average increase in yield due to treatments= average treatment yield- control yield .

\section{RESULTS AND DISCUSSION}

\section{Leaf width, length, area and chlorophyll content}

Data presented in table (3) show that all treatments were significantly effective on Le-Conte "pear" leaf width, length, area and chlorophyll content. However, (TI) $(1 \mathrm{~g} / \mathrm{L})$ gave the highest values from leaf width $(6.71$ and $6.46 \mathrm{~cm})$, leaf length $(9.67$ and $9.46 \mathrm{~cm})$, leaf area (23.98 and $22.73 \mathrm{~cm}^{2}$ ), and chlorophyll content (52.28 and 48.78) in both seasons, respectively followed by (TI) $(0.75 \mathrm{~g} / \mathrm{L})$. In addition, the control was the lowest values in this respect.

\section{Evaluation of the treatment efficiency:}

The efficiency of (TI) and (FA) for leaf width, length, area and chlorophyll content of pear trees compered to soil application shown in (table 4 and Fig.1). The highest increase in pear vegetative growth 
percentages was obtained by (TI) $(25.98 \%)$ followed by (FA) $(13.10 \%)$ compared with the (SA), whereas the lowest one (11.38\%) obtained at (TI) compared to (FA).

In addition, comparing (TI) with (SA) gave the highest increases percentage in leaf width, length, area and chlorophyll content were $(24.61,33.60,17.94$ and $27.79 \%$, respectively) followed by (TI) that compared to (FA).

These results may be due to that trunk injection supplied the element directly to the respective tissues and therefore helps the plant to overcome the nutritional deficiencies caused by soil alkalinity. So, using this method help us to solve absorption problem Abdi and Hedayat (2010). Good growth occurred with the injection-fertilization plants may be attributed to nutrient integration and balance occurring within plant tissues, which led to better physiological expression of the nutrients. Nutrient balance and integration within plant tissues is a key factor for healthy growth and good crop yield Marschner, (1995), Shaaban (2001) and shaaban and bdel-Maguid (2004).

Table 3. Effect of application methods by some micronutrients on some vegetative parameters of pear trees grown in calcareous soil during 2016 and 2017 seasons

\begin{tabular}{lcccccccc}
\multirow{2}{*}{$\begin{array}{c}\text { Properties } \\
\text { *Treatments }\end{array}$} & \multicolumn{2}{c}{ Leaf width $(\mathbf{c m})$} & \multicolumn{2}{c}{ Leaf length $(\mathbf{c m})$} & \multicolumn{2}{c}{ Leaf area $\left(\mathbf{c m}^{2}\right)$} & \multicolumn{2}{c}{$\begin{array}{c}\text { Chlorophyll } \\
\text { content (SPAD) }\end{array}$} \\
\cline { 2 - 9 } & $\begin{array}{c}\text { Season } \\
\mathbf{2 0 1 6}\end{array}$ & $\begin{array}{c}\text { Season } \\
\mathbf{2 0 1 7}\end{array}$ & $\begin{array}{c}\text { Season } \\
\mathbf{2 0 1 6}\end{array}$ & $\begin{array}{c}\text { Season } \\
\mathbf{2 0 1 7}\end{array}$ & $\begin{array}{c}\text { Season } \\
\mathbf{2 0 1 6}\end{array}$ & $\begin{array}{c}\text { Season } \\
\mathbf{2 0 1 7}\end{array}$ & $\begin{array}{c}\text { Season } \\
\mathbf{2 0 1 6}\end{array}$ & $\begin{array}{c}\text { Season } \\
\mathbf{2 0 1 7}\end{array}$ \\
\hline Control & 4.66 & 4.41 & 6.48 & 6.24 & 18.98 & 17.72 & 37.46 & 34.40 \\
SA (50 g/tree) & 5.41 & 5.16 & 7.28 & 7.04 & 20.43 & 19.18 & 41.27 & 37.84 \\
FA (0.5g/l) & 5.46 & 5.21 & 7.62 & 7.39 & 20.80 & 19.55 & 44.23 & 40.73 \\
FA (0.75g/L) & 5.71 & 5.45 & 8.30 & 8.06 & 21.00 & 19.74 & 45.49 & 44.64 \\
FA (1g/L) & 6.00 & 5.64 & 8.68 & 8.46 & 21.78 & 20.53 & 48.14 & 43.51 \\
TI (0.5 g/L) & 5.86 & 5.60 & 8.64 & 8.39 & 22.76 & 20.2 & 47.01 & 41.99 \\
TI (0.75g/L) & 6.06 & 5.81 & 8.94 & 8.69 & 21.47 & 21.51 & 50.87 & 47.23 \\
TI (1g/L) & 6.71 & 6.46 & 9.67 & 9.46 & 23.98 & 22.73 & 52.28 & 48.78 \\
LSD0.05 & 0.017 & 0.017 & 0.018 & 0.016 & 0.901 & 0.611 & 1.131 & 1.363 \\
\hline
\end{tabular}

Means having the same letter in each column are not significantly different at 5\% level *(SA) soil application, (FA) foliar application and (TI) trunk injection

Table 4. The nutrient efficiency for leaf width, length, area and chlorophyll percentage in relation to the application methods

\begin{tabular}{lccccc} 
Properties & Leaf width & Leaf length & Leaf area & Mean \\
comparison Pairs & & & & & \\
\hline FA compared to SA & 10.10 & 19.70 & 6.82 & 15.81 & 13.10 \\
TI compared to SA & 24.61 & 33.60 & 17.94 & 27.79 & 25.98 \\
TI compared to FA & 13.18 & 11.61 & 10.40 & 10.35 & 11.38 \\
\hline
\end{tabular}

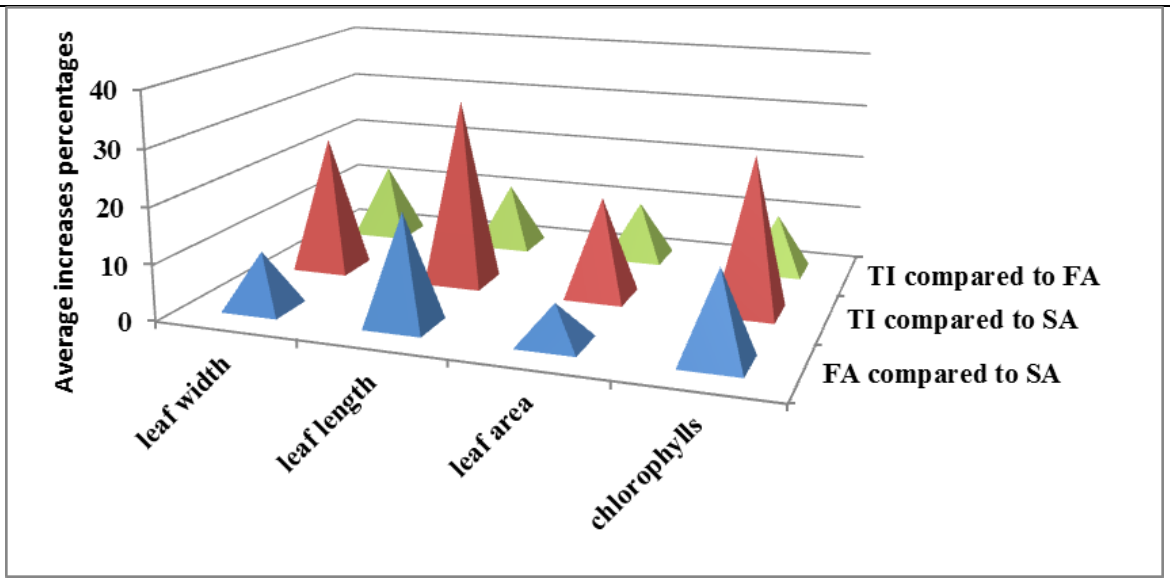

Fig.1.The nutrient efficiency for leaf width, length, area and chlorophyll percentage in relation to the application methods. 
These results are parallel with those of Mahmoud (2009) who showed that dicotyledonous vascular trees (mango and grapevine) can be fully fertilized by injection through xylem. He added that only $5-10 \%$ of the levels that added to the soil were sufficient for good growth. Moreover, growth of the injection-fertilized mango trees was $20-25 \%$ higher than soil-fertilized plants.

\section{Pear leaf nutrients content:}

Data presented in table (5) declare that all treatments were significantly effective on leaf nutrients contents of Le-Conte "pear", where the highest values of leaf N, P, $\mathrm{K}, \mathrm{Ca}$ and $\mathrm{Mg}$ content recorded by (TI) (1g/L) treatment, followed by $(\mathrm{TI})(0.75 \mathrm{~g} / \mathrm{L})$ treatment in the first and second seasons. On the reverse, the lowest content of these nutrients was recorded by control treatment in both seasons.

\section{Evaluation of the treatment efficiency:}

To recognize the efficiency of (TI) and (FA) of micronutrients in calcareous soil in terms of their effect on leaf macro and secondary nutrients content of pear trees, the average of both studied seasons in the increases percentage that achieved at both methods of application were calculated in comparison between those two types of application or compared to the soil application as shown in table 6

As illustrated in Fig.2, it can be concluded that the highest increased percentages in pear leaf macro and secondary nutrients content were obtained with (TI) (14.3\%) followed by (FA) $(8.4 \%)$ whereas the lowest one $(5.4 \%)$ was obtained with (TI) compared to (FA) (Table 6 and Fig.2).

The highest percentage in leaf macro and secondary nutrients content were 6.6, 27.0, 16.4, 11.1 and 10.3\% for $\mathrm{N}, \mathrm{P}, \mathrm{K}, \mathrm{Mg}$ and $\mathrm{Ca}$, respectively when (TI) compared with (SA). It can be concluded that trunk injection is the most efficient method at all as compared to the others for pear trees grown in calcareous soil (Table 6 and Fig.2).

These mentioned results are in harmony with those obtained by Taiz and Zeiger (1998), Mahmoud (2009), Abdi and Hedayat ( 2010), Paula et al., (2015) and Jahanshah et al., (2016).

Table5. Effect of application methods by some micronutrients on pear leaf some nutrients content during 2016 and 2017 seasons

\begin{tabular}{|c|c|c|c|c|c|c|c|c|c|c|}
\hline \multirow{2}{*}{$\begin{array}{l}\text { Nutrient element } \\
\text { *Treatments }\end{array}$} & \multicolumn{2}{|c|}{ N\% } & \multicolumn{2}{|c|}{ P\% } & \multicolumn{2}{|c|}{ K\% } & \multicolumn{2}{|c|}{ Mg\% } & \multicolumn{2}{|c|}{$\mathrm{Ca} \%$} \\
\hline & $\begin{array}{c}\text { Season } \\
2016 \\
\end{array}$ & $\begin{array}{c}\text { Season } \\
2017 \\
\end{array}$ & $\begin{array}{c}\text { Season } \\
2016 \\
\end{array}$ & $\begin{array}{c}\text { Season } \\
2017 \\
\end{array}$ & $\begin{array}{c}\text { Season } \\
2016 \\
\end{array}$ & $\begin{array}{c}\text { Season } \\
2017 \\
\end{array}$ & $\begin{array}{c}\text { Season } \\
2016 \\
\end{array}$ & $\begin{array}{c}\text { Season } \\
2017\end{array}$ & $\begin{array}{c}\text { Season } \\
2016\end{array}$ & $\begin{array}{c}\text { Season } \\
2017\end{array}$ \\
\hline Control & 2.44 & 2.59 & 0.13 & 0.14 & 1.02 & 1.03 & 0.27 & 0.27 & 1.53 & 1.55 \\
\hline SA (50 g/tree) & 2.49 & 2.6 & 0.1 & 0.1 & 1.03 & 1.0 & 0.29 & 0.27 & 1.60 & 1.62 \\
\hline FA $(0.5 \mathrm{~g} / \mathrm{l})$ & 2.53 & 2.6 & & & & $1 .($ & 0.29 & & 1.63 & 1.63 \\
\hline FA & 2.48 & $2 . c$ & 0.1 & & 1.16 & 1.1 & 0.29 & 0.2 & 1.66 & 1.68 \\
\hline FA ( & 2.4 & 2.60 & 0.1 & & 1.18 & 1.2 & 0.29 & 0.2 & 1.70 & 1.71 \\
\hline & 2.50 & 2.6 & 0.15 & 0.1 & 1.18 & 1.1 & 0.29 & 0.2 & 1.71 & 1.73 \\
\hline TI $(0.75 \mathrm{~g} / \mathrm{L})$ & 2.60 & 2.75 & 0.16 & 0.16 & 1.18 & 1.20 & 0.30 & 0.29 & 1.76 & 1.78 \\
\hline TI (1g/L) & 2.66 & 2.80 & 0.16 & 0.17 & 1.20 & 1.22 & 0.31 & 0.30 & 1.77 & 1.78 \\
\hline \#Optimum level & \multicolumn{2}{|c|}{$2.3-2.8$} & \multicolumn{2}{|c|}{$\underline{0.15-0.20}$} & \multicolumn{2}{|c|}{$\underline{1.1-1.5}$} & \multicolumn{2}{|c|}{$\underline{0.25-0.35}$} & \multicolumn{2}{|c|}{$\underline{1.1-2.0}$} \\
\hline LSD0.05 & 0.013 & 0.019 & 0.008 & 0.007 & 0.007 & 0.007 & 0.008 & 0.007 & 0.013 & 0.099 \\
\hline
\end{tabular}

Means having the same letter in each column are not significantly different at 5\% level *(SA) soil application, (FA) foliar application and (TI) trunk injection. \# Utilized from Leece (1976), Jones et al. (1991) and Bright (2005).

Table 6. The nutrient efficiency for leaf nutrients content percentage in relation to the application methods

\begin{tabular}{lcccccc}
\hline Nutrient element & N & P & K & Mg & Ca & Mean \\
\hline FA compared to SA & 1.3 & 15.6 & 14.5 & 4.7 & 5.9 & 8.4 \\
TI compared to SA & 6.6 & 27.0 & 16.4 & 11.1 & 10.3 & 14.3 \\
TI compared to FA & 5.2 & 10.0 & 1.7 & 6.1 & 4.1 & 5.4 \\
\hline
\end{tabular}

*(SA) Soil application, (FA) Foliar application and (TI) Trunk injection 


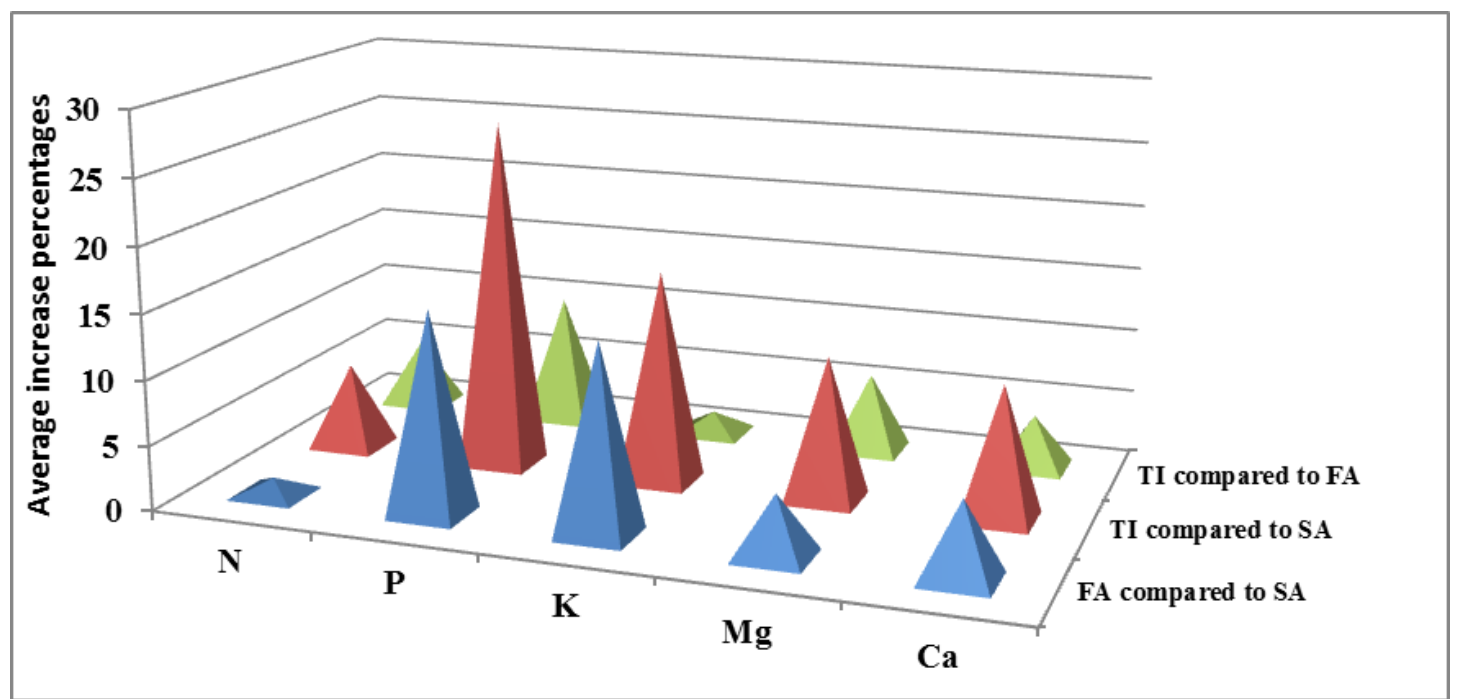

Fig.2. The nutrient efficiency for leaf nutrients content percentage in relation to the application methods

Pear leaf micronutrients content:

Data in table 7 reveal that all treatments were significantly affect leaf micronutrient contents of LeConte "pear". The highest values of leaf $\mathrm{Fe}, \mathrm{Mn}, \mathrm{Zn}, \mathrm{Cu}$ and B content were scored by $(\mathrm{TI})(1 \mathrm{~g} / \mathrm{L})$, followed by (TI) $(0.75 \mathrm{~g} / \mathrm{L})$ in both seasons. On contrary, the lowest pear leaf content of these micronutrients was recorded by control in both seasons followed by (SA).

\section{Evaluation of the treatment efficiency:}

To recognize the efficiency of (TI) and (FA) for micronutrients in calcareous soil in terms of their effect on leaf micronutrients content, the average increases percentage of both studied seasons that achieved at both methods of application were calculated in comparison between those two types of application or compared to the (SA) as shown in table 8.

Table7. Effect of application methods by some micronutrients on leaf micronutrient content of pear trees grown in calcareous soil during 2016 and 2017 seasons

\begin{tabular}{|c|c|c|c|c|c|c|c|c|c|c|}
\hline \multirow{2}{*}{$\begin{array}{l}\text { Nutrient element } \\
\text { *Treatments }\end{array}$} & \multicolumn{2}{|c|}{$\mathrm{Fe}(\mathrm{ppm})$} & \multicolumn{2}{|c|}{ Mn (ppm) } & \multicolumn{2}{|c|}{ Zn (ppm) } & \multicolumn{2}{|c|}{$\mathrm{Cu}(\mathrm{ppm})$} & \multicolumn{2}{|c|}{ B (ppm) } \\
\hline & $\begin{array}{c}\text { Season } \\
2016 \\
\end{array}$ & $\begin{array}{c}\text { Season } \\
2017 \\
\end{array}$ & $\begin{array}{c}\text { Season } \\
2016 \\
\end{array}$ & $\begin{array}{c}\text { Season } \\
2017 \\
\end{array}$ & $\begin{array}{c}\text { Season } \\
2016 \\
\end{array}$ & $\begin{array}{c}\text { Season } \\
2017 \\
\end{array}$ & $\begin{array}{c}\text { Season } \\
2016 \\
\end{array}$ & $\begin{array}{c}\text { Season } \\
2017 \\
\end{array}$ & $\begin{array}{c}\text { Season } \\
2016 \\
\end{array}$ & $\begin{array}{c}\text { Season } \\
2017 \\
\end{array}$ \\
\hline Control & 136.80 & 138.00 & 38.00 & 36.50 & 15.74 & 16.54 & 6.90 & 6.51 & 40.21 & 38.83 \\
\hline SA $(50 \mathrm{~g} /$ tree $)$ & 147.30 & 148.50 & 48.00 & 47.00 & 16.60 & 17.78 & 7.40 & 7.01 & 44.94 & 44.25 \\
\hline FA $(0.5 \mathrm{~g} / \mathrm{l})$ & 167.80 & 170.50 & 54.00 & 53.50 & 26.80 & 27.60 & 7.90 & 7.43 & 47.2 & 46.75 \\
\hline FA $(0.75 \mathrm{~g} / \mathrm{L})$ & 157.80 & 160.00 & 54.00 & 52.66 & 29.80 & 30.61 & 8.15 & 7.50 & 45.84 & 46.01 \\
\hline FA $(1 \mathrm{~g} / \mathrm{L})$ & 174.80 & 176.00 & 56.00 & 56.50 & 27.90 & 28.69 & 8.61 & 8.77 & 45.71 & 46.00 \\
\hline TI $(0.5 \mathrm{~g} / \mathrm{L})$ & 164.30 & 165.50 & 56.50 & 55.50 & 31.90 & 32.71 & 7.90 & 7.55 & 45.54 & 45.25 \\
\hline TI $(0.75 \mathrm{~g} / \mathrm{L})$ & 175.80 & 177.00 & 62.00 & 62.50 & 41.70 & 42.54 & 8.81 & 8.88 & 46.31 & 45.76 \\
\hline TI (1g/L) & 177.30 & 178.06 & 62.00 & 63.33 & 43.70 & 44.51 & 8.90 & 9.07 & 46.74 & 45.84 \\
\hline \#Optimum level & \multicolumn{2}{|c|}{$60-200$} & \multicolumn{2}{|c|}{$25-100$} & \multicolumn{2}{|c|}{$16-50$} & \multicolumn{2}{|c|}{$\underline{6-20}$} & \multicolumn{2}{|c|}{$20-60$} \\
\hline$\overline{\text { LSD0.05 }}$ & $0.51 \overline{1}$ & $\overline{0.510}$ & $0.2 \overline{75}$ & 0.304 & $0.35 \overline{5}$ & 0.352 & $0.02 \overline{4}$ & 0.035 & $0.07 \overline{6}$ & 0.089 \\
\hline
\end{tabular}

Means having the same letter in each column are not significantly different at 5\% level *(SA) soil application, (FA) foliar application and (TI) trunk injection. \# Utilized from Leece (1976), Jones et al. (1991) and Bright (2005).

Table 8. The nutrient efficiency for leaf macronutrients content percentage in relation to the application methods

\begin{tabular}{|c|c|c|c|c|c|c|}
\hline $\begin{array}{l}\text { Nutrient element } \\
\text { Comparison pairs }\end{array}$ & $\mathbf{F e}$ & Mn & $\mathbf{Z n}$ & $\mathrm{Cu}$ & B & Mean \\
\hline FA compared to SA & 18.6 & 18.4 & 64.7 & 20.7 & 2.8 & 25.1 \\
\hline TI compared to $\mathrm{SA}$ & 20.1 & 32.0 & 156.8 & 24.8 & 3.8 & 47.5 \\
\hline TI compared to FA & 1.3 & 11.4 & 55.9 & 3.4 & 1.0 & 14.6 \\
\hline
\end{tabular}

*(SA) Soil application, (FA) Foliar application and (TI) Trunk injection 
As illustrated in Fig.3, it can be concluded that the highest increase percentages in pear leaf micronutrients content was obtained with (TI) $(47.5 \%)$ followed by (FA) $(25.1 \%)$ when comparing with (SA) whereas the lowest one $(14.6 \%)$ was obtained with (TI) compared to (FA) (Table 8 and Fig.3).

The highest values percentage in leaf micronutrients contents of pear trees were 20.1, 32.0, 156.8, 24.8 and $3.8 \%$ for $\mathrm{Fe}, \mathrm{Mn}, \mathrm{Zn}, \mathrm{Cu}$ and $\mathrm{B}$, respectively, when compared (TI) with (SA) (Table8 and Fig.3).

Based on the obtained results, it can be concluded that micronutrients application could be useful for improving the nutrient status and physiological performance of pear plants especially under micronutrients deficiency conditions such as growing in calcareous soil. This may be due to that micronutrients are required in small amounts and they affect directly or indirectly photosynthesis, vital processes in plant such as respiration, protein synthesis, reproduction phase. Manganese has an essential role in amino acid synthesis by activating a number of enzymes particularly decarboxylases and dehydrogenases of the tricarboxylic acid cycle. Iron is a constituent of many enzymes involved in the nutritional metabolism of plant. Zinc plays an important role as a metal component of enzymes (superoxide dismutase, carbonic anhydrase and RNA polymerase) or as a functional, structural, or regulator cofactor of a large number of enzymes Marschner (1995), El-Fouly et al., (1997) and KabataPendias and Pendias (1999), El-Fouly, et al., (2010) and El-Fouly, et al., (2011).

These results are in harmony with those obtained by Taiz, and Zeiger (1998), Mahmoud (2009), Abdi and
Hedayat ( 2010), Paula et al., (2015) and Jahanshah et al., (2016).

\section{Total yield (kg/tree) and number of fruits /tree}

Concerning the results in table (9) total yield and number of fruits was significantly affected by all treatments in both seasons. Furthermore, (TI) $(1 \mathrm{~g} / \mathrm{L})$ gave the highest values of total yield (112.02 and $113.07 \mathrm{~kg} / \mathrm{tree}$ ) and the highest number of fruits (376.7 and 378.3 fruits/tree) in the first and second season respectively, followed by (TI) $(0.75 \mathrm{~g} / \mathrm{L})$ compared the lowest values obtained from control in both seasons.

\section{Evaluation of the treatment efficiency:}

Data in table (10) and Fig.4. show the efficiency of (TI) and (FA) for total yield and number of fruits of pear in calcareous soil and their effect. The highest total yield and number of fruits was obtained at (TI) (28.73 and $11.69 \%)$ followed by (FA) (13.78 and6.66\%) compared with (SA), while (TI) compared to (FA) was the lowest values of total yield and number of fruits (13.14 and $4.72 \%$ ) respectively in the average of both seasons.

This observed results occurred by trunk injection with $\mathrm{Fe}, \mathrm{Zn}$ and $\mathrm{cu}$ fertilizer appeared to be more efficient than soil application. Despite the large amounts of micro elements in most calcareous soils, the availability of this nutrients for the plants usually very low, due to the effect of high $\mathrm{pH}$ on the formation of insoluble iron compounds in soil Brady and Weil (2008). Trunk injection supplies the elements directly to the respective tissues and therefore helps the plant to overcome the nutritional challenges caused by soil alkalinity. Enhancing availability of iron to plant results in an increase in photosynthesis and carbohydrate transportation in plant tissues, thereby increasing yield level Mengel and Kirkby (1978).

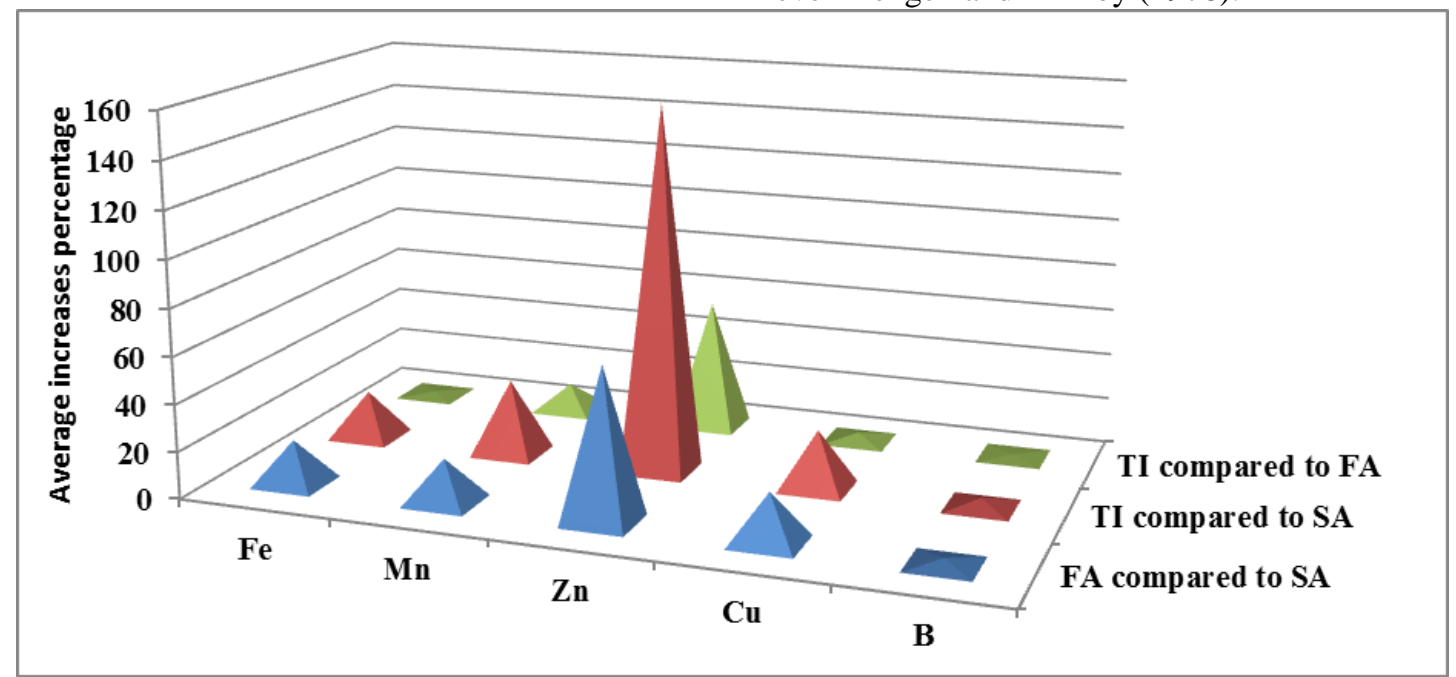

Fig.3. The nutrient efficiency for leaf macronutrients content percentage in relation to the application methods 
Table 9. Effect of application methods by some micronutrients on yield parameters of pear trees grown in calcareous soil during 2016 and 2017 seasons

\begin{tabular}{lcccc}
\hline & \multirow{2}{*}{ Properties } & \multicolumn{2}{c}{ Total yield kg/tree } & \multicolumn{2}{c}{ Number of fruits /tree } \\
\cline { 2 - 5 } *Treatments & \multirow{2}{*}{ Season2016 } & $\begin{array}{c}\text { Season } \\
\mathbf{2 0 1 7}\end{array}$ & $\begin{array}{c}\text { Season } \\
\mathbf{2 0 1 6}\end{array}$ & $\begin{array}{c}\text { Season } \\
\mathbf{2 0 1 7}\end{array}$ \\
\hline Control & 84.45 & 82.62 & 331.3 & 331.3 \\
SA $(\mathbf{5 0} \mathbf{g} /$ tree) & 86.66 & 88.20 & 336.7 & 339.3 \\
FA $(\mathbf{0 . 5} / \mathbf{l})$ & 89.35 & 91.43 & 341.0 & 345.7 \\
FA $(\mathbf{0 . 7 5} / \mathbf{L})$ & 93.97 & 96.61 & 351.3 & 355.7 \\
FA (1g/L) & 98.29 & 100.66 & 360.0 & 361.0 \\
TI $(\mathbf{0 . 5} \mathbf{g} / \mathbf{L})$ & 104.75 & 106.23 & 367.7 & 369.7 \\
TI $(\mathbf{0 . 7 5 g} / \mathbf{L})$ & 109.14 & 110.33 & 373.3 & 376.0 \\
TI $(\mathbf{1 g} / \mathbf{L})$ & 112.02 & 113.07 & 376.7 & 378.3 \\
LSD0.05 & 0.283 & 0.3023 & 0.627 & 0.665 \\
\hline
\end{tabular}

Means having the same letter in each column are not significantly different at 5\% level *(SA) soil application, (FA) foliar application and (TI) trunk injection

Table 10. The nutrient efficiency for total yield and number of fruits percentage in relation to the application methods

\begin{tabular}{lcccc}
\hline & Properties & Total yield & Number of fruits & Mean \\
Comparison pairs & & 13.78 & 6.66 & 10.22 \\
\hline FA compared to SA & 28.73 & 11.69 & 20.21 \\
TI compared to SA & 13.14 & 4.72 & 8.93 \\
\hline TI compared to FA & & &
\end{tabular}

*(SA) Soil application, (FA) Foliar application and (TI) Trunk injection

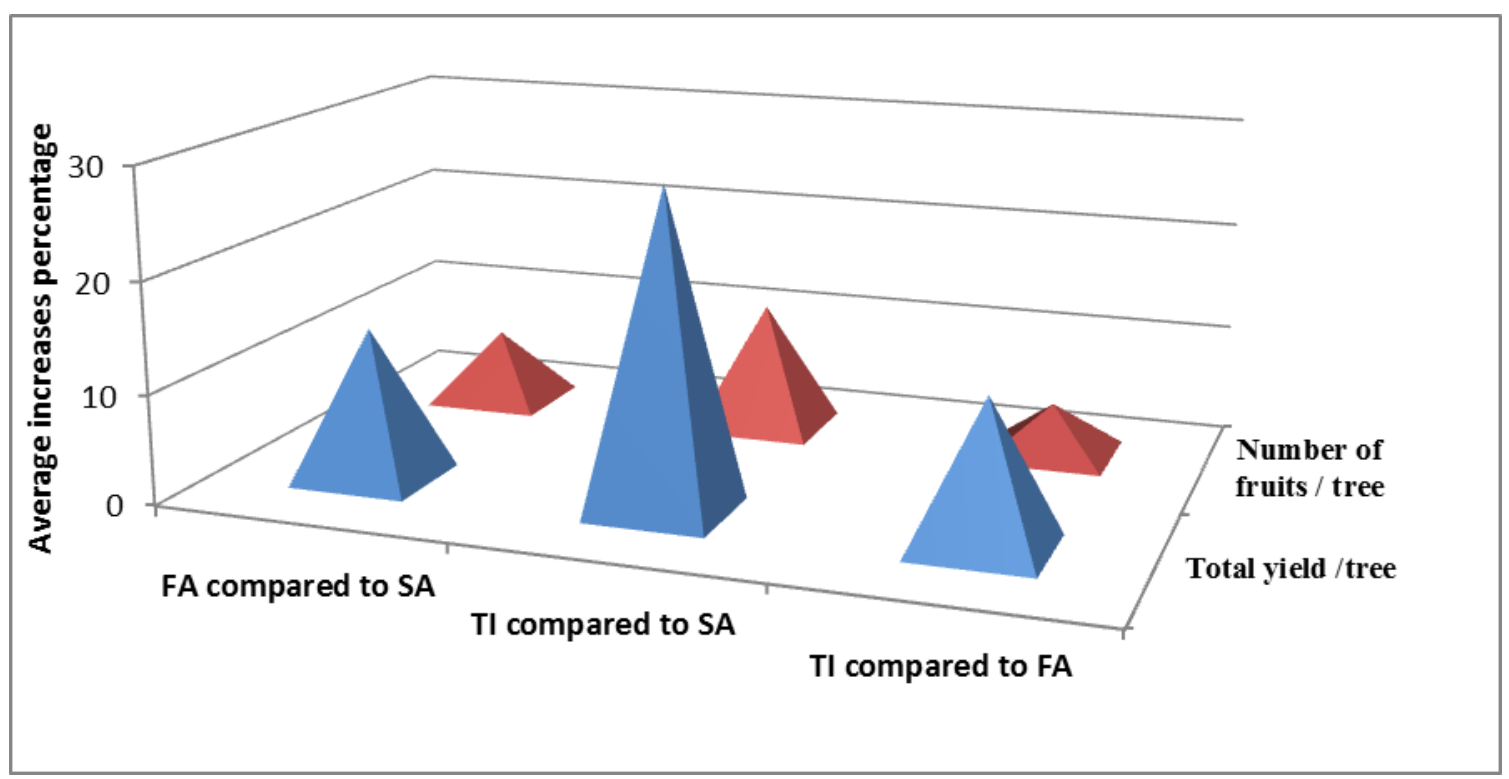

Fig 4. The nutrient efficiency for total yield and number of fruits percentage in relation to the application methods

Generally, these results are in agreement with those of Mahmoud (2009) who showed that dicotyledonous vascular trees (mango and grapevine) can be fully fertilized by injection through xylem. Only $5-10 \%$ of the levels used in soil fertilization were sufficient for good yield. While in grapevine fruit yield increased 32-49\% higher compared to soil fertilization. Paula et al., (2015) Showed that giving injections to the trunk as a supplement to soil fertilization increased fruit production significantly in Valencia orange fruit. 
Considerable yield enhancement with trunk injection of micro elements compounds was also reported by other researchers Abdi and Hedayat (2010).

Fruit length $(\mathrm{cm})$, diameter $(\mathrm{cm})$, weight $(\mathrm{g})$ and volume $\left(\mathrm{cm}^{3}\right)$

From the data in table (11) it is evident that fruit length, diameter, weight and volume of Le-Conte "pear" were significantly affected by all treatments in both seasons. Moreover, (TI) $(1 \mathrm{~g} / \mathrm{L})$ gave the highest values of fruit length $(8.46$ and $8.26 \mathrm{~cm})$, fruit diameter $(6.54$ and $6.66 \mathrm{~cm})$, fruit weight $(297.40$ and $298.90 \mathrm{~g})$ and fruit volume (283.33 and $\left.288.10 \mathrm{~cm}^{3}\right)$ in the $1^{\text {st }}$ and the $2^{\text {nd }}$ season respectively. On the other hand, control gave the minimum values of fruit length $(7.32$ and $7.12 \mathrm{~cm})$, fruit diameter $(5.60$ and $5.72 \mathrm{~cm})$, fruit weight $(244.87$ and $249.37 \mathrm{~g}$ ) and fruit volume (248.50 and $\left.247.27 \mathrm{~cm}^{3}\right)$ in the $1^{\text {st }}$ and the $2^{\text {nd }}$ season respectively.

\section{Evaluation of the treatment efficiency:}

The efficiency of (TI) and (FA) for fruit length, diameter, weight and volume of Le-Conte "pear" trees were shown in (table 12 and fig.5). The highest fruit length, diameter, weight and fruit volume obtained with (TI) $(9.31 \%)$ followed by (FA) $(4.64 \%)$ compared with the (SA), while the lowest one $(4.47 \%)$ was obtained at (TI) compared to (FA).
In addition, (TI) with comparing (SA) gave the highest increases in fruit length, diameter, weight and volume of pear trees percentage $(6.38,3.85,15.27$ and $11.95 \%$ respectively) followed by (TI) compared to (FA) (table12 and fig.5).

\section{Total sugars, TSS and total acidity \%}

Data in tables (13) revealed that total sugars, total soluble solid (TSS) and total acidity of Le-Conte "pear" was significantly affected by all treatments in both seasons. It is cleared that (TI) $(0.5,0.75$ and $1 \mathrm{~g} / \mathrm{L})$ gave the best total sugars and TSS in first season, while (TI) $(1 \mathrm{~g} / \mathrm{L})$ gave the best total sugars and TSS in second season. In addition, (TI) $(1 \mathrm{~g} / \mathrm{L})$ decreased total acidity in both seasons.

\section{Evaluation of the treatment efficiency:}

The efficiency of (TI) and (FA) for total sugars, soluble solid and total acidity of Le-Conte "pear" trees were shown in (table 14and fig.6). (TI) with (SA) gave the highest increases percentage in total sugars and total soluble solid and the highest decrease percentage decrease of total acidity $(31.90,20.81$ and $-31.42 \%$ respectively) followed by (TI) compared to (FA) only for TSS and acidity. The lowest increases percentage in total soluble solid and the lowest decrease percentage in total acidity were observed at (FA) compared to (SA) (table14 and fig.6).

Table 11. Effect of application methods of some micronutrients on fruit physical properties of pear trees grown in calcareous soil during 2016 and 2017 seasons

\begin{tabular}{lccccccccc}
\hline & \multirow{2}{*}{ Properties } & \multicolumn{2}{c}{$\begin{array}{c}\text { Fruit length } \\
(\mathbf{c m})\end{array}$} & \multicolumn{2}{c}{$\begin{array}{c}\text { Fruit diameter } \\
(\mathbf{c m})\end{array}$} & \multicolumn{2}{c}{$\begin{array}{c}\text { Fruit weight } \\
(\mathbf{g})\end{array}$} & \multicolumn{2}{c}{$\begin{array}{c}\text { Fruit volume } \\
\left(\mathbf{c m}^{\mathbf{3}}\right)\end{array}$} \\
\cline { 3 - 10 } Treatments & $\begin{array}{c}\text { Season } \\
\mathbf{2 0 1 6}\end{array}$ & $\begin{array}{c}\text { Season } \\
\mathbf{2 0 1 7}\end{array}$ & $\begin{array}{c}\text { Season } \\
\mathbf{2 0 1 6}\end{array}$ & $\begin{array}{c}\text { Season } \\
\mathbf{2 0 1 7}\end{array}$ & $\begin{array}{c}\text { Season } \\
\mathbf{2 0 1 6}\end{array}$ & $\begin{array}{c}\text { Season } \\
\mathbf{2 0 1 7}\end{array}$ & $\begin{array}{c}\text { Season } \\
\mathbf{2 0 1 6}\end{array}$ & $\begin{array}{c}\text { Season } \\
\mathbf{2 0 1 7}\end{array}$ \\
\hline Control & 7.32 & 7.12 & 5.60 & 5.72 & 244.87 & 249.37 & 248.50 & 247.27 \\
SA (50 g/tree) & 8.15 & 7.58 & 6.30 & 6.41 & 257.40 & 259.90 & 254.17 & 256.27 \\
FA (0.5g/l) & 7.78 & 7.58 & 5.97 & 6.08 & 262.03 & 264.53 & 262.33 & 264.44 \\
FA (0.75g/L) & 7.85 & 7.72 & 6.30 & 6.42 & 267.47 & 271.63 & 265.83 & 267.94 \\
FA (1g/L) & 8.21 & 7.99 & 6.42 & 6.53 & 273.02 & 278.85 & 270.25 & 272.02 \\
TI (0.5 g/L) & 8.15 & 7.57 & 6.21 & 6.32 & 284.90 & 287.40 & 274.33 & 276.10 \\
TI (0.75g/L) & 8.32 & 8.06 & 6.46 & 6.57 & 292.35 & 293.52 & 277.75 & 282.52 \\
TI (1g/L) & 8.46 & 8.26 & 6.54 & 6.66 & 297.40 & 298.90 & 283.33 & 288.10 \\
LSD0.05 & 0.082 & 0.017 & 0.015 & 0.015 & 4.68 & 5.64 & 5.12 & 7.83 \\
\hline
\end{tabular}

Means having the same letter in each column are not significantly different at $5 \%$ level *(SA) soil application, (FA) foliar application and (TI) trunk injection

Table 12. The nutrient efficiency for fruit length, fruit diameter, fruit weight and fruit volume percentage in relation to the application methods

\begin{tabular}{|c|c|c|c|c|c|}
\hline $\begin{array}{ll}\text { Comparison pairs } & \text { Properties } \\
\end{array}$ & $\begin{array}{l}\text { Fruit } \\
\text { length }\end{array}$ & $\begin{array}{c}\text { Fruit } \\
\text { diameter }\end{array}$ & Fruit weight & $\begin{array}{c}\text { Fruit } \\
\text { volume }\end{array}$ & Mean \\
\hline FA compared to $\mathrm{SA}$ & 3.07 & 1.88 & 6.68 & 6.24 & 4.47 \\
\hline TI compared to $S A$ & 6.38 & 3.85 & 15.27 & 11.95 & 9.316 \\
\hline TI compared to FA & 3.21 & 1.92 & 8.05 & 5.37 & 4.64 \\
\hline
\end{tabular}

*(SA) Soil application, (FA) Foliar application and (TI) Trunk injection 


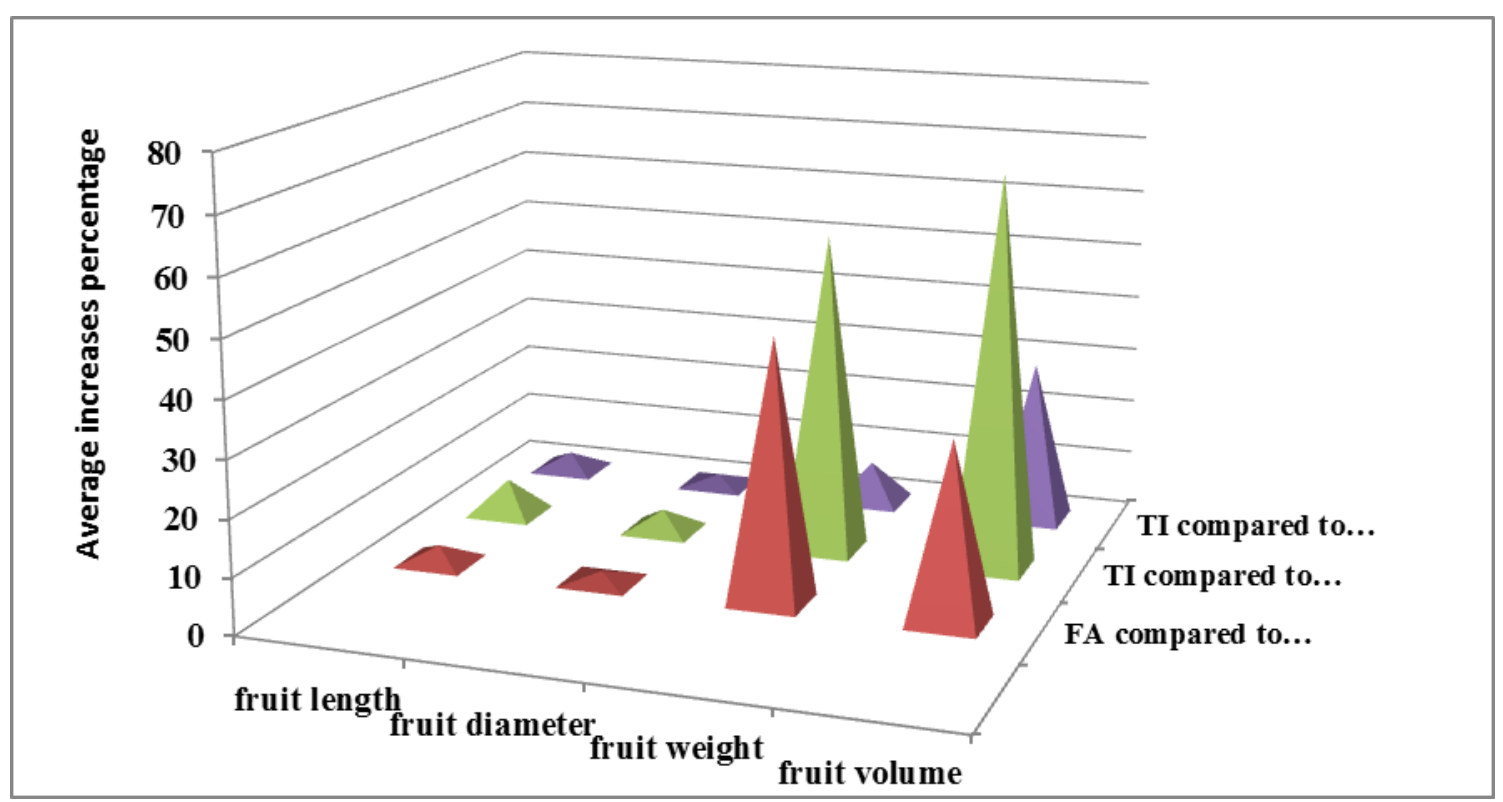

Fig.5. The nutrient efficiency for fruit length, fruit diameter, fruit weight and fruit volume percentage in relation to the application methods

Table 13. Effect application methods of some micronutrients on some fruit chemical properties of pear trees grown in calcareous soil during 2016 and 2017 seasons

\begin{tabular}{lcccccc}
\hline & \multicolumn{2}{c}{ Total sugars\% } & \multicolumn{2}{c}{ TSS\% } & \multicolumn{2}{c}{ Acidity\% } \\
\cline { 2 - 7 } Treatments & $\begin{array}{c}\text { Season } \\
\mathbf{2 0 1 6}\end{array}$ & $\begin{array}{c}\text { Season } \\
\mathbf{2 0 1 7}\end{array}$ & $\begin{array}{c}\text { Season } \\
\mathbf{2 0 1 6}\end{array}$ & $\begin{array}{c}\text { Season } \\
\mathbf{2 0 1 7}\end{array}$ & $\begin{array}{c}\text { Season } \\
\mathbf{2 0 1 6}\end{array}$ & $\begin{array}{c}\text { Season } \\
\mathbf{2 0 1 7}\end{array}$ \\
\hline Control & 9.49 & 10.33 & 12.14 & 12.31 & 0.36 & 0.38 \\
SA $(\mathbf{5 0} \mathbf{g} /$ tree) & 9.55 & 10.41 & 12.29 & 12.55 & 0.35 & 0.35 \\
FA $(\mathbf{0 . 5 g} / \mathbf{l})$ & 10.41 & 11.21 & 12.86 & 12.98 & 0.33 & 0.34 \\
FA $(\mathbf{0 . 7 5 g / L )}$ & 10.90 & 11.71 & 12.98 & 13.31 & 0.29 & 0.34 \\
FA $(\mathbf{1 g} / \mathbf{L})$ & 11.46 & 12.25 & 13.07 & 13.50 & 0.28 & 0.34 \\
TI $(\mathbf{0 . 5} \mathbf{g} / \mathbf{L})$ & 12.40 & 13.04 & 14.34 & 14.66 & 0.27 & 0.31 \\
TI $(\mathbf{0 . 7 5 g / L )}$ & 12.46 & 13.19 & 14.52 & 14.98 & 0.25 & 0.30 \\
TI $(\mathbf{1 g} / \mathbf{L})$ & 12.80 & 13.51 & 14.61 & 15.22 & 0.24 & 0.24 \\
LSD0.05 & 0.790 & 0.048 & 0.583 & 0.217 & 0.083 & 0.013 \\
\hline
\end{tabular}
Means having the same letter in each column are not significantly different at $5 \%$ level *(SA) soil application, (FA) foliar application and (TI) trunk injection

Table 14. The nutrient efficiency for some fruit chemical properties in relation to the application methods

\begin{tabular}{lccc}
\hline comparison pairs & Total sugars & TSS & Acidity \\
\hline FA compared to SA & 18.83 & 6.48 & -11.42 \\
TI compared to SA & 31.90 & 20.81 & -31.42 \\
TI compared to FA & 10.98 & 13.45 & -21.84 \\
\hline
\end{tabular}

*(SA) Soil application, (FA) Foliar application and (TI) Trunk injection 


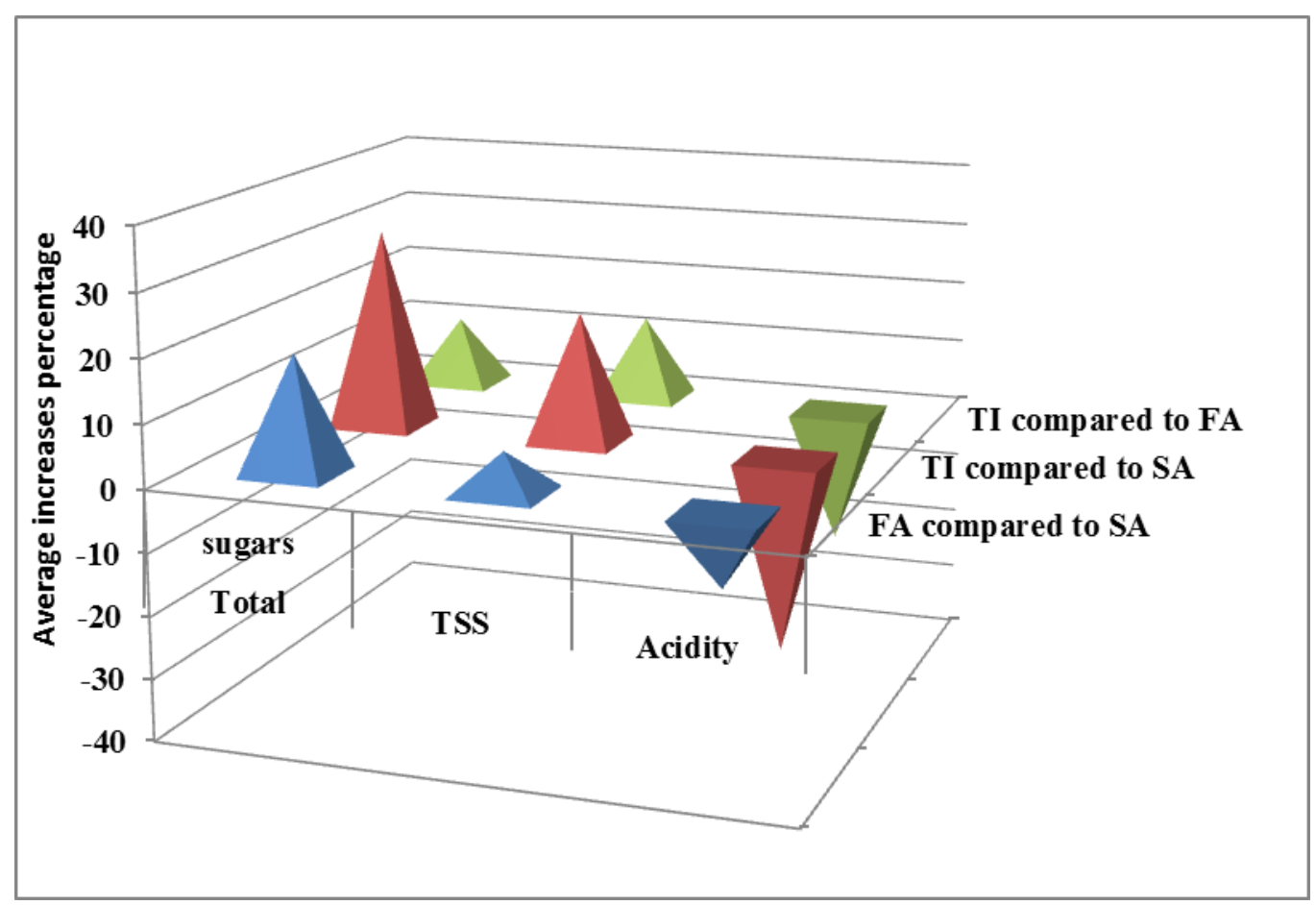

Fig.6. The nutrient efficiency for some fruit chemical in relation to the application methods

Those obtained results may be adequate concentrations of these elements realized by injection fertilization could explain the higher fruit yield and quality. Trunk injection of an acidic solution of $\mathrm{FeSO}_{4}$, not only supplies adequate iron for photosynthesis, but also may improve availability and translocation of other nutrients such as Zinc, Manganese and phosphorus by diminution of the plant sap pH L. Taiz, and Zeiger (1998).

These results in tables 11,13 are in parallel with those of Abdi and Hedayat (2010) who showed that the usefulness of nutritional injections to the trunk as a complement to the conventional fertilization in commercial plantations, the use of injections to the trunk could reduce the cost of fertilizer application with the benefit of increased fruit production without unchanged quality parameters. In addition Jahanshah et al., (2016) concluded that trunk injection is a more efficient method for iron fertilization of date palms grown in calcareous soils. Fe at $200 \mathrm{mg} / \mathrm{l}$ injection to trunk increased TSS, fruit weight, flesh weight, fruit size, total, reducing and non-reducing sugars of date palm. Trunk injection works better than other methods in calcareous soils in date palm.

\section{Correlation coefficients}

As shown in table (15) it can be concluded that all pear leaf nutrients content had significant appositive correlation coefficients among all fruit yield, physical and chemical properties except acidity where they had correlate negatively with fruit acidity. Magnesium leaf content achieved the highest significant values of positive correlation coefficients for all fruit yield, physical and chemical properties i.e. 0.96, 0.97, 0.92, $0.87,0.99,0.99,0.95$ and 0.94 for tolal yield/tree, fruit length, fruit diameter, fruit weight, fruit volume, total sugar and TSS, respectively. Fruit volume achieved most of the highest significant positive correlations with most of pear leaf nutrients content i.e. 0.80, 0.97, 0.98, 0.99, 0.90, 0.93, 0.90 for $\mathrm{N}, \mathrm{P}, \mathrm{Ca}, \mathrm{Mg}, \mathrm{Fe}, \mathrm{Mn}$ and $\mathrm{B}$, respectively.

These observations are in harmony with those mentioned by many authors as Sparrow and Graham (1988), Marschner (1995), Imsande (1998), Amao and Ohashi (2008) and Millaleo et al., (2010) where they stated that there a noticeable physiological common functions, especially concerning photosynthesis process which are directly related to fruit properties, among these three micronutrients (i.e. $\mathrm{Zn}, \mathrm{Fe}$ and $\mathrm{Mn}$ ) where $\mathrm{Fe}$ is essential for the synthesis of chlorophyll, involved in nitrogen fixation and photosynthesis, $\mathrm{Zn}$ is necessary for producing chlorophyll and forming carbohydrate and $\mathrm{Mn}$ is indirectly related to chlorophyll formation where it activates several important metabolic reactions in the plants and is involved in the evolution of $\mathrm{O}_{2}$ in photosynthesis

\section{Economic analysis}

Economic analysis of pear CV. Le-Conte yield (MT/fed) under the varying under studied methods of 
Table 15. Correlation coefficients between leaf nutrient contents and both of fruit yield and fruit physical and chemical properties of pear plant due to trunk injection and foliar application by some micronutrients in calcareous soil through average of both studied seasons

\begin{tabular}{cccccccccc}
$\begin{array}{c}\text { properties } \\
\text { nutrient element }\end{array}$ & $\begin{array}{c}\text { Total } \\
\text { yield/tree }\end{array}$ & $\begin{array}{c}\text { Fruits } \\
\text { No/tree }\end{array}$ & $\begin{array}{c}\text { Fruit } \\
\text { length }\end{array}$ & $\begin{array}{c}\text { Fruit } \\
\text { diameter }\end{array}$ & $\begin{array}{c}\text { Fruit } \\
\text { weight }\end{array}$ & $\begin{array}{c}\text { Fruit } \\
\text { volume }\end{array}$ & $\begin{array}{c}\text { Total } \\
\text { sugar }\end{array}$ & TSS & Acidity \\
\hline $\mathbf{N}$ & 0.68 & 0.67 & 0.76 & 0.64 & 0.78 & 0.80 & 0.67 & 0.77 & -0.63 \\
$\mathbf{P}$ & 0.92 & 0.92 & 0.82 & 0.73 & 0.94 & 0.97 & 0.94 & 0.91 & -0.91 \\
$\mathbf{K}$ & 0.91 & 0.94 & 0.80 & 0.80 & 0.90 & 0.91 & 0.92 & 0.85 & -0.82 \\
$\mathbf{C a}$ & 0.91 & 0.91 & 0.91 & 0.83 & 0.96 & 0.98 & 0.91 & 0.92 & -0.84 \\
$\mathbf{M g}$ & 0.96 & 0.97 & 0.92 & 0.87 & 0.99 & 0.99 & 0.95 & 0.94 & -0.86 \\
$\mathbf{F e}$ & 0.83 & 0.83 & 0.84 & 0.75 & 0.85 & 0.90 & 0.84 & 0.78 & -0.78 \\
$\mathbf{M n}$ & 0.91 & 0.90 & 0.89 & 0.83 & 0.92 & 0.93 & 0.89 & 0.86 & -0.88 \\
$\mathbf{Z n}$ & 0.94 & 0.91 & 0.77 & 0.68 & 0.93 & 0.92 & 0.94 & 0.93 & -0.95 \\
$\mathbf{C u}$ & 0.58 & 0.59 & 0.77 & 0.77 & 0.67 & 0.74 & 0.59 & 0.56 & -0.54 \\
$\mathbf{B}$ & 0.88 & 0.89 & 0.90 & 0.83 & 0.88 & 0.90 & 0.86 & 0.80 & -0.84 \\
\hline
\end{tabular}

Table16. Profitability per fed of Pear CV. Le-Conte yield (MT/fed; 168tree/fed) grown in calcareous soil as affected by trunk injection and foliar application by some micronutrients

\begin{tabular}{lccccc}
\hline $\begin{array}{c}\text { Methods of micronutrients } \\
\text { applications }\end{array}$ & $\begin{array}{c}\text { Average } \\
\text { yield } \\
\text { MT/fed }\end{array}$ & $\begin{array}{c}\text { Average } \\
\text { increase in } \\
\text { yield MT/fed }\end{array}$ & $\begin{array}{c}\text { Treatment } \\
\text { cost LE/fed }\end{array}$ & $\begin{array}{c}\text { Treatment } \\
\text { profit LE/fed }\end{array}$ & $\begin{array}{c}\text { Net return } \\
\text { LE/fed }\end{array}$ \\
\hline Control & 14.03 & 0 & 0 & 0 & 0 \\
SA (50 g/tree) & 14.69 & 0.654 & 1700 & 1962.862 & 262.8616 \\
FA (0.5g/l) & 15.19 & 1.152 & 1000 & 3456.869 & 2456.869 \\
FA (0.75g/L) & 16.01 & 1.975 & 1100 & 5924.612 & 4824.612 \\
FA (19/L) & 16.71 & 2.678 & 1200 & 8033.575 & 6833.575 \\
TI (0.5 g/L) & 17.72 & 3.689 & 1700 & 11066.72 & 9366.723 \\
TI (0.75g/L) & 18.44 & 4.402 & 1800 & 13207.23 & 11407.23 \\
TI (19/L) & 18.91 & 4.874 & 1900 & 14622.98 & 12722.98 \\
\hline
\end{tabular}

*(SA) Soil application, (FA) Foliar application and (TI) Trunk injection

micronutrients application treatments are shown in table(16) data indicated that application of micronutrients either with foliar or trunk injection resulted in higher benefit and net return compared to that of both control (no application) and soil application. The treatments of trunk injection application surpassed all foliar application treatments either in profit or net return values. In addition the treatment of trunk injection application at $1 \mathrm{~g}$ micronutrients/L achieved the maximum total profit $(14622.98 \mathrm{LE} / \mathrm{fed})$ and the maximum net return value $(12722.98 \mathrm{LE} / \mathrm{fed})$ followed by the net return values (11407.23 and 9366.723LE/fed) for both treatments of trunk injection at 0.75 and $0.5 \mathrm{~g} / \mathrm{L}$, respectively. On the other hand, the lowest net return value $(262.8616 \mathrm{LE} / \mathrm{fed})$ was observed at soil injection treatment at $50 \mathrm{~g} /$ tree.

\section{CONCLUSION}

It can be concluded that trunk injection is the most efficient method at all, compared to the other treatments of applying micronutrients to pear trees. It could be added that trunk injection is saving a great amount of micronutrients fertilizers and it is an environment friendly fertilization method to overcome micronutrients deficiency problems in calcareous soils.

\section{REFERENCES}

A.O.A.C. 2000. Official Methods of Analysis. 17th Edition, The Association of Official Analytical Chemists, Gaithersburg, MD, USA. Methods 925.10. 65.17: 974.24-992.16.

Abdi G. and M. Hedayat. 2010. Yield and fruit physiochemical characteristic of "Kabkab" date palm as affected by methods of iron fertilization. World Applied Sci. J. 10(11):1328-1333

Alloway, B.J. 2008. Zinc in soils and crop nutrition. International Zinc Association Brussel, Belgium. Int.J.Curr.Microbiol.App.Sci (2017) 6(6): 3240-3250.

Álvarez-Fernández A., P. García-Laviña, C. Fidalgo, J. Abadía and A. Abadía. 2004. Foliar fertilization to control iron chlorosis in pear (Pyrus communis L.) trees. Plant Soil 263:5-15. 
Amao, Y. and A. Ohashi 2008. Effect of Mn ion on the visible light induced water oxidation activity of photosynthetic organ grana from spinach. Catalysis Communication, 10: 217-220

Asaad, S.A. 2014. The influence of spraying sitofex, iron, manganese and zinc on 'Anna' apple trees planted on new reclaimed calcareous land. Life Sci. J. 11:1-8.

Atallah, E.S., W.M. Abd EL-Messeih and G.B. Mikhael . 2010. Using of Natural Raw Material Mixture and Magnetite Raw (Magnetic Iron) as Substitute for Chemical Fertilizers in Feeding "Le Conte" Pear Trees Planted in Calcareous Soil. Alex. Sci. Exch. J. 31: 51 - 62.

Bakshi, P., A. Jasrotia, V.K. Wali, A. Sharma and M. Bakshi. 2013.Influence of pre-harvest application of calcium and micro-nutrients on growth, yield, quality and shelf-life of strawberry cv. Chandler. Indian J. Agri. Sci., 83(8): 831835.

Başar, H. 2003. Analytical methods for evaluating iron chlorosis in peach trees. Communications Soil Sci. Plant Analysis 34(3-4):327-341

Brady, N. C. and R. R. Weil 2008. The Nature and Properties of Soils, 14th ed., Upper Saddle River, New Jersey, USA: Pearson Education Inc.,

Bremner, J.M. 1965.Inorganic Forms of Nitrogen. In: Black, C.A., et al., Eds., Methods of Soil Analysis, Part 2, Agronomy Monograph No. 9, ASA and SSSA, Madison:1179-1237.

Bright, J. 2005. Apple and pear nutrition. NWS Department of Primary Industries. Primefact Number: 85,

First Edition 1 October 2005. Available at: http://ucanr.org/sites/nm/files/76700.pdf (Accessed: 20 April 2016)

Chapman, H.D. and P.F. Pratt .1961. Methods of Analysis for Soils, Plants and Waters. University of California, Los Angeles.60-61: 150-179.

El-Fouly, M.M., Z.M. Mobarak and Z.A. Salama. 1997. Comparative study on the effect of chelated multimicronutrient compounds on the growth and nutrient uptake in some plants. Egypt J. Physiol. Sci., 21: 447-458.

El-Fouly, M.M., Z. M. Mobarak and Z.A. Salama. 2010. Improving tolerance of faba bean during early growth stage to salinity through micronutrients foliar spray. Not. Sci. Biol. 2: 98-102.

El-Fouly, M.M., Z.M. Mobarak and Z.A. Salama. 2011. Micronutrients (Fe, Mn, Zn) foliar spray for increasing salinity tolerance in wheat Triticum aestivum L. African J. Plant Sci. 5(5):314-322.

El-Khawga, A.S. 2007. Reduction in fruit cracking in manfaluty pomegranate following a foliar application with paclobutrazol and Zinc sulphate. J. Applied Sci. Res. 3(9): $837-840$

Gomez, K.A. and Gomez A.A. 1984.Statistical procedures for agricultural research, 2nd edn. John Wiley and Sons, New York
Imsande, J. 1998. Iron, sulfur, and chlorophyll deficiencies: A need for an integrative approach in plant physiology. Plant Physiol. 103:139-144.

Jackson, M. L. 1958. Soil Chemical Analysis. Prentice Hall Inc., Englewood Chiffs, 213-214.

Jahanshah S., Y. Hosseini, and M. Ghoreishi. 2016. Is Trunk Injection More Efficient Than Other Iron Fertilization Methods in Date Palms Grown in Calcareous Soils J. Advan. Agric.Technologies 3:160-163

Jones, J.B. Jr., B. Wolf, ve H.A. Mills. 1991. Plant Analysis Handbook. Micro Macro Publishing, Inc.

Kacar, B. and A.ve Inal. 2008.Bitki analizleri. Nobel Yayın Dagitim Ltd. Sti., Ankara, 876 pp.

Kabata-Pendias, A. and H. Pendias, 1999. Biogeochemistry of Trace Elements. PWN, Warsaw, Poland.

Leece, D.R. (1976). Leaf compositional standards for stone fruit and pome fruit. Diagnosis of nutritional

disorders of fruit trees by leaf and soil analyses and biochemical indices. J. Aust. Inst. Agric. Sci. 42: 3-19.

Marschner, H., 1995. Mineral Nutrition of Higher Plants. Academic Press Inc. London LTD

Mahmoud, M. S. 2009. Injection fertilization : A Full nutritional technique for fruit trees saves $90-95 \%$ of fertilizers and maintains a clean environment. Fruit, Vegetable Cereal Sci. Biotechnology 3. (1): 22-27.

Mohamad, F., A. Hassan, M. H. Omaima and A. K. Salwa. 2017. Enhancing le-conte pear trees performance by foliar spray with different Iron concentrations. AgricEngInt: CIGR Journal Open access at http://www.cigrjournal.org: 201-210.

Mengel K. and E. Kirkby 1978. Principles of Plant Nutrition, Berne: Int. Potash Inst.,book

Moazzam A., F.M. Tahir, J. Shahzad and N. Mahmood. 2011. Effect of foliar application of micronutrients on the quality of mango (Mangifera indica L.) cv. Dusehri fruit. Mycopath, 9(1): 25-28.

Millaleo, R., D. M. Reyes, A. G. Ivanov, M. L.Mora and M. A. lberdi. 2010. Manganese as essential and toxic element for plants transport, accumulation and resistance mechanisms. J. Soil Sci. Plant Nutri., 10(4): 470-481

Navarro, C., R. y. F. Escobar and M. A. Benlloch. 1992. low-pressure, trunk-injection method for introducing chemical formulations into olive trees. J. American Society for Horticultural Sci., 117. : 357-360.

Parkinson, J.A. and S. E. Allen 1975. A wet oxidation procedure suitable for the determination of nitrogen and mineral nutrients in biological materials.Commun. Soil Sci. Plant Anal. 6: 1-11.

Paula A. L., M. M. Y. Elvira, M. D. C.1 Monzón, S. M. M. Jeandet,V. A. R. S.A Ramos and G. C. M. Bearzzotti . 2015. Effects of nutritional trunk injections on valencia late orange production Cultivos Tropicales.36 : 142-147 
Ram, R.A. and T.K. Bose. 2000. Effect of foliar application of magnesium and micronutrients on growth, yield and fruit quality of mandarin orange (Citrus reticulata Blanco). Indian J. of Horticulture, 57(3): 215-220

Shaaban M. M. 2001. Effect of trace-nutrient foliar fertilizer on nutrient balance, growth, yield and yield components of two cereal crops. Pakistan J. Biological Sci. 4:770-774

Shaaban M. M, M. M. El-Fouly and A. A. Abdel-Maguid (2004) Zinc-boron relation- ship in wheat plants grown under low or high levels of calcium carbonate in the soil. Pakistan J. Biological Sci. 7, 633-639

Shoeib M.M. and A. El Sayyed .2003. Response of Thompson seedless grape vines to the spray of some nutrients and citric acid. Minia J. Agri. Res. Development 23(4):681-698.

Smith, M. B., J. S. Bruner and R. W. White. 1956. Opinions and personality. New York: John Wiley
Sohrab D., M. Akbari, M. A. Askari, M. Babalar, and M. E.Naddaf. 2013. Effect of iron foliar application (FeEDDHA) on quantitative and qualitative characteristics of pomegranate cv. "Malas -e-Saveh". World Sci. J., (04):179-187.

Sparrow, D. H. and R. D. Graham 1988. Susceptibility of zinc deficient wheat plants to colonization by Fusarium graminearum Schw. Group 1. Plant and Soil, 112: 261266.

Swietlik, D. 2002. Zinc nutrition of fruit trees by foliar sprays, Acta Hort. 594: 123-129.

Taiz, L. and E. Zeiger.1998. Plant Physiology. 2nd Edition, Sinauer Associates Publishers, Sunderland, Massachusetts. http://dx.doi.org/10.1071/PP9840361.

Waskela R.S., R. N. Kanpure, B. R. Kumawat and B. K. Kachouli .2013. Effect of foliar spray of micronutrients on growth, yield and quality of guava (Psidium guajava L.) cv. Dharidar. Inter. J. Agri. Sci. 9(2):551-556.

Yadav, V., P.N. Singh and P. Yadav. 2013. Effect of foliar fertilization of boron, zinc and iron on fruit growth and yield of low-chill peach cv. Sharbati international J. Scientific Res. Publications, 3(8): 1-6. 


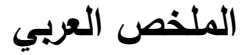

استجابة أشجار الكمثرى الليكونت النامية في أرض جيرية لحقن الجذع والرش الورقى لبعض العناصر الصغرى

عيد محمد احمد زين الدين - محرم فؤاد عطيه- شيرين عادل عبد الحميد

الحصاد في "أغسطس ) وقد أظهرت النتائج أن حقن

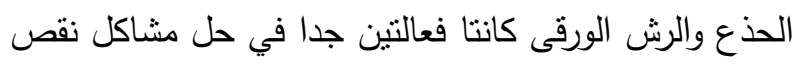

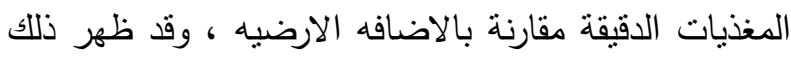
على تحسن فى القياسات الخضريه (عرض الورقة ، طول بلإل

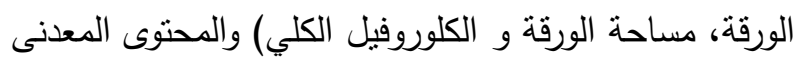

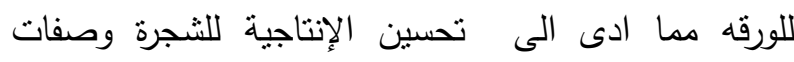

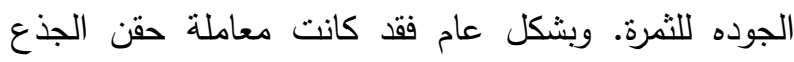

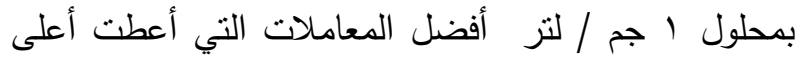

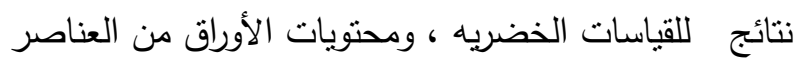

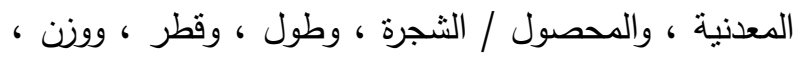
وحجم الثمرة ، والسكريات الكليه ، و المواد الصلبه الذائبه

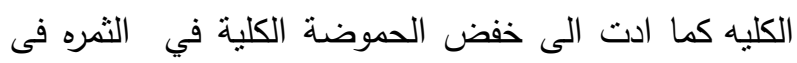

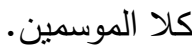

أجريت هذه الدراسة خلال الموسمين المنتاليين 17. 17 و و

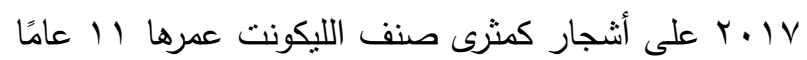
بمزرعه في مدينة الحمام بمحافظة مطروح، بجمهورية مصرالعربية للتغلب على مشاكل نقص المغذيات الدقيقة في

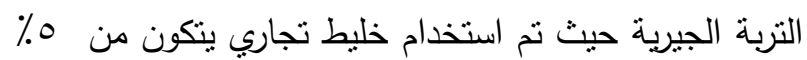

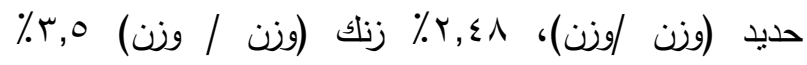

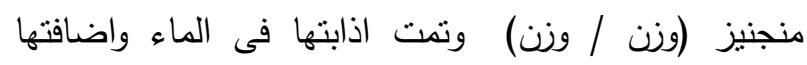

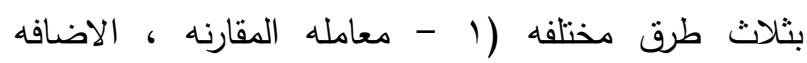

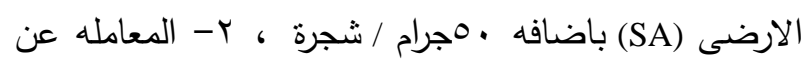

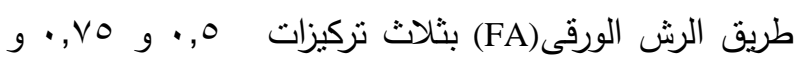

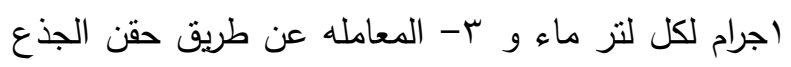

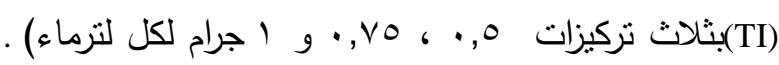

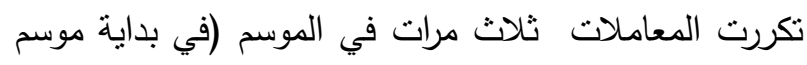

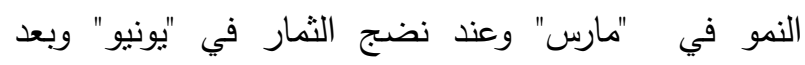

